\title{
Effects of Epidural Bupivacaine on the Doses of Propofol, Alfentanil, Vecuronium, and Neuromuscular Block: A Prospective Randomized, Single-Blind Clinical Study
}

\author{
Epidural Bupivakainin Propofol, Alfentanil, \\ Veküronyum Dozlarına ve Nöromusküler Blok Üzerine \\ Etkisi: Randomize Prospektif, Tek Kör Klinik Çalışma
}

\author{
Bülent KARLILAR, \\ Mehtap TUNÇ, \\ Hilal GÜNAL SAZAK, \\ Ayça TELATAR, ${ }^{\circ}$ \\ Eser ŞAVKILIOĞLU, \\ Erdem KARABULUT'
}

${ }^{a}$ Clinic of Anesthesiology and

Reanimation,

Umut Surgical Medical Center, Mersin

${ }^{\mathrm{b}}$ Anesthesiology and Reanimation

Atatürk Pulmonary Diseases and

Surgery Training and Research Hospital,

Ankara

'Anesthesiology and Reanimation,

Sinop State Hospital, Sinop

dDepartment of biostatistics,

Hacettepe University

Faculty of Medicine, Ankara

Geliş Tarihi/Received: 10.12.2011

Kabul Tarihi/Accepted: 04.12.2012

Yazışma Adresi/Correspondence: Bülent KARLILAR

Umut Surgical Medical Center,

Anesthesiology and Reanimation,

Mersin,

TÜRKIYE/TURKEY

bulentkarlilar@gmail.com

doi: 10.5336/medsci.2011-27673

Copyright $(02013$ by Türkiye Klinikleri
ABSTRACT Objective: This study was planned to ascertain the effects of epidural bupivacaine on the doses of propofol, alfentanil and vecuronium used for the maintenance for general anesthesia in patients receiving thoracic epidural anesthesia (TEA) combined with total intravenous anesthesia (TIVA) in thoracic surgery. In addition, the impacts of TEA on duration, intensity, reversal and the characteristics of residual block related to vecuronium-induced neuromuscular blockade was investigated. Material and Methods: Thirty patients scheduled for thoracic surgery were randomly assigned into two groups. Group 1 received TIVA combined with TEA, whereas Group 2 obtained TIVA solely. Epidural bupivacaine (0.375\%) was given $6 \mathrm{~mL} / \mathrm{h}$ following $1.5 \mathrm{~mL} /$ segment bupivacaine $(0.5 \%)$ bolus in Group 1. General anesthesia was provided with propofol, alfentanil and vecuronium in both groups. Propofol dose was adjusted to maintain bispectral index (BIS) value between 45 and 60 , whereas alfentanil dose was titrated according to the hemodynamic parameters. Following neuromuscular monitoring and stabilization of response to the neuromuscular stimulus, $0.1 \mathrm{mg} / \mathrm{kg}$ vecuronium was injected intravenously in 5 seconds. The responses to train of four (TOF) stimulation (TOF1 and TOF2), posttetanic count (PTC), and TOF rate (TOFR) values were recorded. The neuromuscular blockade was reversed after closure of surgical incision and the fourth response to TOF during recovery. The residual block was assessed in surgical intensive care unit for 30 minutes. Results: Alfentanil amount used in the maintenance was significantly less in Group 1 compared to Group 2 ( $\mathrm{p}<0.05$ ), whereas there was no difference between the groups for propofol and vecuronium doses ( $p>0.05)$. There was no statistically significant difference between the groups with respect to the onset time of vecuronium, TOF1 time following induction, and duration of the clinical effects of vecuronium used for induction and maintenance ( $>0.05)$. Conclusion: It was demonstrated that epidural bupivacaine decreased the requirement of alfentanil without alterations in propofol and vecuronium doses in patients undergoing thoracic surgery in our study. We also suggest that in the present dose, epidural bupivacaine has no effect on duration, intensity, reversal or the characteristics of residual block related to vecuronium-induced neuromuscular blockade.

Key Words: Anesthesia, general; methods; anesthesia, epidural; anesthetics, local; bupivacaine; monitoring, intraoperative; neuromuscular blockade; vecuronium bromide; transmission

ÖZET Amaç: Bu çalıșma, toraks cerrahisinde total intravenöz anestezi (TİVA) ile kombine torakal epidural anestezi (TEA) uygulanan hastalarda epidural bupivakainin, anestezi idamesinde kullanılan propofol, alfentanil ve veküronyum dozlarına etkisini belirlemek için planlandı. Ayrıca TEA'nın, veküronyuma bağlı gelişen nöromusküler blok süresi, derinliği, geri döndürme ve rezidüel blok karakteristikleri üzerine etkileri araştırıldı. Gereç ve Yöntemler: Toraks cerrahisi planlanan 30 hasta rastgele iki gruba ayrıldı. Grup 1'e TİVA ile kombine TEA, Grup 2'ye yalnız TIVA uyguland. Grup 1'deki hastalara epidural bupivakain (\%0,5, 1,5 mL/segment) puşeyi takiben \%0,375 bupivakain, $6 \mathrm{~mL} / \mathrm{sa} \mathrm{hızda} \mathrm{infüze} \mathrm{edildi.} \mathrm{Genel} \mathrm{anestezi} \mathrm{her} \mathrm{iki} \mathrm{grupta} \mathrm{propofol,} \mathrm{alfentanil} \mathrm{ve} \mathrm{vekuronyum} \mathrm{ile} \mathrm{sağlandı.} \mathrm{Pro-}$ pofol dozu hedef bispektral index (BIS) değeri 45-60 olacak şekilde, alfentanil dozu hemodinamik değişikliklere göre ayarlandı. Nöromuskuler monitörizasyon sonrası nöromusküler uyarıya sabit yanıt alınmaya başladığında $0,1 \mathrm{mg} / \mathrm{kg}$ veküronyum 5 sn'de verildi. Dörtlü uyarıya alınan yanıtlar (TOF1 ve TOF2), posttetanik sayım (PTC), TOF oranı (TOFR) değerleri kaydedildi. Derlenme sırasında; cerrahi insizyon bittiğinde ve TOF’a 4. yanıttan sonra nöromusküler blok geri çevrildi. Cerrahi yoğun bakımda $30 \mathrm{dk}$ süreyle rezidüel blok değerlendirildi. Bulgular: Grup 1'de kullanılan idame alfentanil dozları Grup 2 ile karşılaştırıldığında, istatistiksel olarak anlamlı derecede azaldığı $(\mathrm{p}<0,05)$, propofol ve veküronyum dozları arasında fark olmadığı bulunmuștur $(p>0,05)$. Gruplar arasında vekuronyumun etki başlama süresi, indüksiyon sonrası TOF1 süresi, indüksiyon ve idame kas gevşeticilerin klinik etki süreleri açısından farklılık bulunmamıştır ( $>>0,05)$. Sonuç: Çalışmamızda; toraks cerrahisi uygulanan olgularda, epidural yolla verilen bupivakainin, alfentanil ihtiyacını azalttı̆̆ı; propofol ve vekuronyum dozlarını değiștirmediği bulundu. Yine bu çalışmadaki dozlarda epidural bupivakainin; veküronyuma bağlı gelişen nöromusküler bloğun süre, yoğunluk, geri döndürme ve rezidüel blok karakteristikleri üzerine etkisi olmadığı gösterildi.

Anahtar Kelimeler: Anestezi, genel; yöntemler; anestezi, epidural; anestezikler, lokal; bupivakain; monitörize etme, operasyonda; nöromüsküler blokaj; vekuronyum bromür; iletim

Turkiye Klinikleri J Med Sci 2013;33(2):306-13 
$\mathrm{T}$ he state of general anesthesia has two major components. First is the defeat of consciousness and recall, which is found to correlate with the bispectral index (BIS). The second component is suppression of reflex responses (somatic, motor, hemodynamic or endocrine) to a noxious stimulus. During unconsciousness, a noxious stimulus may result in awakening. The noxious stimulus could be kept from reaching superior centers by opiates, hypnotics and local anesthetics. The level of consciousness, and the BIS, is affected by a painful stimulus and this response is suppressed by an opioid or an increasing concentration of propofol. ${ }^{1}$

Epidurally administered bupivacaine is considered to provide an excellent analgesia at the operation field in addition to muscle relaxation by neuraxial blockade. ${ }^{2}$ General anesthesia combined with epidural anesthesia could decrease the side effects by creating reduced requirement of the anesthetic agents and potentiating the positive impacts. ${ }^{3-5}$ Several mechanisms have been suggested for interaction of local and general anesthetics. One of these is the inhibition of the tonic afferent spinal nerve signaling to the brain and spinal cord above the level of neural blockade by epidurally given local anesthetic. ${ }^{6}$ The other mechanism is inhibition of neurotransmission in the nerves by local anesthetics and propofol. ${ }^{7}$ To our knowledge, there are limited number of studies indicating that epidural local anesthetics decrease maintenance dose of propofol, opioid and muscle relaxants.

We designed this study to investigate whether thoracal epidural anesthesia (TEA) combined with total intravenous anesthesia (TIVA) decreases the requirement of intravenous (IV) anesthetics in thoracic surgery. In addition, we wanted to investigate whether epidural bupivacaine altered duration, intensity and the reversal characteristics of vecuronium-induced neuromuscular blockade (NMB).

\section{MATERIAL AND METHODS}

Thirty adults, in American Society of Anesthesiologists physical status I-II, that scheduled for elective thoracotomy were randomly assigned to two groups by sealed envelope method after the approval of institutional Human Investigation Ethics Committee (decision number:107/1, 3.2.2006) and obtaining informed consents from the patients. Group 1 (no: 15) received TEA combined with TIVA, and Group 2 (no: 15) had TIVA alone.

The present prospective and single-blind clinical study was in compliance with the principles of good clinical practice those applied at the pharmacodynamic studies of neuromuscular blocking agents. ${ }^{8,9}$ The patients with $30 \%$ more or $70 \%$ less than ideal body weight were excluded. Patients with neuromuscular, cardiac, hepatic or renal disorders and those taking glucocorticoid or drugs affecting neuromuscular conduction were excluded from the study. ${ }^{8-10}$ All drugs were used on-label doses. The patients were premedicated with midazolam (Dormicum ${ }^{\circledR}, 5 \mathrm{mg} / 5 \mathrm{~mL}$, Fontenay, France in the name of Switzerland) $0.06 \mathrm{mg} / \mathrm{kg}$ and atropine $0.05 \mathrm{mg} / \mathrm{kg}$ intramuscularly, $45 \mathrm{~min}$ before operation.

The patients in Group 1 were given colloid solution $15 \mathrm{~mL} / \mathrm{kg} / \mathrm{h}$ initially. The epidural catheter was inserted through thoracic 7-8 or 8-9 intervertebral space, using loss of resistance method, with the patients in a sitting position. Motor blockade was evaluated by Bromage scale following test dose of lidocaine HCL ( $2 \%, 3 \mathrm{ml})$. After 20 minutes, sensory blockade was assessed using pin-prick test.

Electrocardiogram, peripheral $\mathrm{O}_{2}$ saturation $\left(\mathrm{SpO}_{2}\right)$, blood pressures, heart rate $(\mathrm{HR})$, central venous pressure and end-tidal carbon dioxide $\left(\mathrm{ETCO}_{2}\right)$ were monitored, and arterial blood gases were analyzed hourly during operations. Peripheral temperature was monitored by skin probes. NMB was monitored by a nerve stimulator, Train of Four (TOF) Watch (TOF-Watch-SR NV Organon, Oss, The Netherlands) during the operation. The skin was cleaned and dried before the TOF Watch electrodes were adhered. ${ }^{8}$ BIS (model A-XP; Aspect Medical Systems, Natick, MA) electrodes were also connected before the induction of anesthesia.

Epidural loading dose of bupivacaine (Marcaine, $5 \mathrm{mg} / \mathrm{mL}$, Astra Zeneca, Turkey) (0.5\%, 1.5 
$\mathrm{mL} /$ segment) was given to affect 5 segments in Group 1. Bupivacaine dose was adjusted to height and age of the patients as follows: it increased by $0.1 \mathrm{~mL} /$ segment for each $5 \mathrm{~cm}$ above $150 \mathrm{~cm}$, and decreased by $0.1 \mathrm{~mL} /$ segment for each 10 years above 40 years.

Anesthesia was induced with iv $20 \mathrm{mcg} / \mathrm{kg}$ alfentanil (Rapifen, $0.5 \mathrm{mg} / \mathrm{mL}$, Janssen, Belgium) and $2 \mathrm{mg} / \mathrm{kg}$ propofol (Propofol, $10 \mathrm{mg} / \mathrm{mL}$, Fresenius, Sweden) in all patients. Then accelerometer device was operated and the patient was ventilated with a mask until stable response to the single stimuli $(1 \mathrm{~Hz})$ was observed. In the maintenance, TIVA with IV propofol (140 mcgr $/ \mathrm{kg} / \mathrm{min}$ ) and alfentanil (1 $\mathrm{mcgr} / \mathrm{kg} / \mathrm{min}$ ), and TEA with epidural bupivacaine $(0.375 \%, 6 \mathrm{~mL} / \mathrm{h})$ infusions were started in Group 1. First, stable muscle response was decided by receiving similar responses above $90 \% .^{8}$ Then, supramaximal response was obtained and calibration was performed. Finally, $0.1 \mathrm{mg} / \mathrm{kg}$ vecuronium was given and the measurements were recorded. Duration of the single response to TOF defined as the onset time and tracheal intubation was performed. The maintenance of anesthesia was provided with propofol and alfentanil infusions in Group 2.

Propofol dose diminished to $100 \mathrm{mcgr} / \mathrm{kg} / \mathrm{min}$ 10 minutes after induction. Posttetanic count (PTC) was controlled every 10 minute-period without response to TOF. After at least 8 responses to PTC, TOF responses were controlled again. When TOF 2 response occurred or diaphragm contraction was seen, $0.04 \mathrm{mg} / \mathrm{kg}$ vecuronium bromide (Norcuron, $10 \mathrm{mg}$, Organon, Netherlands) was administered in the anesthesia maintenance of both groups.

Target BIS value was defined between 45 and 60. Propofol infusion was adjusted to maintain bispectral index value. The propofol dose was decreased $(20 \mathrm{mcg} / \mathrm{kg} / \mathrm{min})$ if BIS value was less than 45 for longer than 5 minutes, and it was increased $(20 \mathrm{mcg} / \mathrm{kg} / \mathrm{min})$ if BIS value was more than 60 . Alfentanil infusion rate was increased by doses of $0.25 \mathrm{mcg} / \mathrm{kg} / \mathrm{min}$ when HR increased as $30 \%$ of the basal value (without hypovolemia) or mean arte- rial pressure (MAP) increased as $20 \%$ of the initial value. When $\mathrm{HR}$ was less than $45 \mathrm{beat} / \mathrm{min}$ for more than 5 minutes or below 40 beat $/ \mathrm{min}$ at any time, it was planned to apply atropine $0.5 \mathrm{mg}$ IV. It was designed to augment the infusion rate of ringer lactate primarily, and then administer ephedrine $10 \mathrm{mg}$ IV when MAP was below $60 \mathrm{mmHg}$ for 5 minutes. If bradycardia or hypotension persisted, atropine or ephedrine was repeated. In the case of no response, opioid infusion rate was decreased by doses of $0.25 \mathrm{mcg} / \mathrm{kg} / \mathrm{min}$.

The routine ventilation strategy (tidal volume: $8 \mathrm{~mL} / \mathrm{kg}$, respiratory rate is adjusted to maintain $\mathrm{ETCO}_{2}$ between 30 and $35 \mathrm{mmHg}$ ) was performed and oxygen $100 \%$ was used during one-lung ventilation in the present study. The peripheral temperature was kept above $32^{\circ} \mathrm{C}$.

Alfentanil infusion was terminated 15 minutes prior to the end of surgery whereas propofol and epidural bupivacaine infusions ended 5 minutes before the surgery was completed. For the purpose of $\mathrm{NMB}$ reversal, $30 \mathrm{mcg} / \mathrm{kg}$ neostigmine and 0.01 $\mathrm{mg} / \mathrm{kg}$ atropin were given after $4^{\text {th }}$ response to TOF during recovery. The trachea was extubated after observation of 0.80 response to TOF, and this time was recorded as recovery time. The patients were admitted to surgical intensive care unit (SICU) after the response to TOF became $>0.90 .{ }^{8}$ In SICU, TOF was controlled every 10 minutes for 30 minutes, comparing the NMB levels, residual curarization was examined in both groups. Total requirement of the anesthetic drugs were calculated in $\mathrm{mg} / \mathrm{kg} / \mathrm{h}$, and difference was assessed between the groups.

Systolic arterial pressure (SAP), diastolic arterial pressure (DAP), MAP, $\mathrm{HR}, \mathrm{SpO}_{2}, \mathrm{ETCO}_{2}$, $\mathrm{BIS}$, and peripheral temperature were recorded throughout the operation, until train of four rate (TOFR) was measured as $90 \%$ at the end.

In the assessment of NMB, onset time (the time beginning from the administration of muscle relaxant to the moment that one response was observed to TOF), clinical effect time (the time beginning from the administration of muscle relaxant to the moment that TOF 2 response and diaphragm contraction was seen), PTC number (counts with 
intervals of 10 minutes after muscle relaxant), duration TOF 0.9 (Start point: time after injection of the last maintenance dose of muscle relaxant, Endpoint: recovery of TOF ratio to 0.90 ), TOFR 25-80 time (the time beginning from the TOFR of $25 \%$ to the moment that TOFR became $80 \%$ ), and reversal time (the time beginning from the neuromuscular antagonism to the moment that TOFR became $80 \%$ ) were evaluated. ${ }^{9}$

\section{STATISTICAL ANALYSIS}

Assuming that epidural administration of bupivacaine will reduce the requirement of anesthetics by $30 \%$, power analysis with alpha 0.05 , powero exclude any dropouts, we included 15 patients in each group. ${ }^{2}$

Data were recorded to a $\mathrm{PC}$ and analyzed using "SPSS for Windows 11.0" software. Chi-square $\left(\chi^{2}\right)$ was used to test the difference between the groups for categorical variables. Normality of the distribution of numerical variables was evaluated by Shapiro-Wilk test. Difference between the two groups was compared with independent sample ttest and Mann Whitney U test for normally and non-normally distributed variables, respectively. A $p$ value of $<0.05$ was considered as statistically significant.

\section{RESULTS}

Patient characteristics and duration of the operation are summarized at (Table 1). There was no statistically significant difference between two groups with respect to demographic data and operation duration, and both of the groups were homogeneous ( $\mathrm{p}>0.05)$.

Regarding the peripheral temperatures, there was no statistically significant difference between the groups during the operation ( $p>0.05)$. The peripheral temperatures were higher than $32^{\circ} \mathrm{C}$ in all patients.

In comparison between the groups, SAP value on the $10^{\text {th }} \mathrm{min}$ of induction was significantly lower in Group 1 ( $\mathrm{p}=0.034$ ). DAP value on the $10^{\text {th }}$ min of $2^{\text {nd }}$ maintenance of vecuronium was significantly lower in Group 1 compared to Group 2
( $\mathrm{p}=0.017$ ) (independent samples t-test and Mann Whitney U test was used).

Two patients from Group 2 received IV ephedrine due to hypotension that was not persistent. We did not find statistically significant difference between the groups in HR values ( $p>0.05)$.

There was no statistically significant difference between two groups with regard to onset time, induction TOF1, and clinical effect times of vecuronium (Table 2) ( $>>0.05)$. There was no statistically significant difference between the groups for PTC values (Table 3) (p>0.05).

There was no statistically significant difference between the groups in the time for the existence of

\begin{tabular}{|c|c|c|c|}
\hline \multicolumn{4}{|c|}{$\begin{array}{l}\text { TABLE 1: Demographic data and duration of the } \\
\text { operation (Mean } \pm S D) \text {. }\end{array}$} \\
\hline & Group $1(n=15)$ & Group $2(n=15)$ & $p$ \\
\hline Age (years) & $35.67 \pm 13.24$ & $40.27 \pm 10.83$ & $0.307^{\circ}$ \\
\hline Weight (kg) & $72.8 \pm 14.44$ & $68.73 \pm 8.6$ & $0.357^{*}$ \\
\hline Height (cm) & $167.13 \pm 10.26$ & $167.6 \pm 8.5$ & $0.893^{*}$ \\
\hline Gender (Female/Male) & $6 / 9$ & $6 / 9$ & $1.000^{* *}$ \\
\hline Operation duration (h) & $3.04 \pm 1.05$ & $2.83 \pm 0.96$ & $0.571^{*}$ \\
\hline
\end{tabular}

*: independent samples t-test; **: Chi-square test.

TABLE 2: Onset time, induction TOF1, clinical effect time of induction and clinical effect time of maintenance with muscle relaxants [Mean \pm SD or Median (Min-Max)].

\begin{tabular}{lccc}
$\begin{array}{l}\text { Timing of neuromuscular } \\
\text { blockage (min) }\end{array}$ & Group 1 $(\mathrm{n}=15)$ & Group 2 $(\mathrm{n}=15)$ & $\mathrm{p}$ \\
Onset time & $3.28 \pm 1.25$ & $3.12 \pm 0.72$ & $0.917^{*}$ \\
TOF1 after induction & $30.02 \pm 9.16$ & $31.83 \pm 8.88$ & $0.820^{*}$ \\
$\begin{array}{l}\text { Clinical effect time of } \\
\text { induction }\end{array}$ & $38.06 \pm 9.69$ & $37.64 \pm 10.57$ & $0.793^{*}$ \\
$\begin{array}{l}\text { Clinical effect time of } \\
1^{\text {st }} \text { maintenance }\end{array}$ & $32.78 \pm 10.84$ & $31.83 \pm 10.32$ & $0.920^{*}$ \\
$\begin{array}{l}\text { Clinical effect time of } \\
2^{\text {nd }} \text { maintenance }\end{array}$ & $36.35 \pm 13.54$ & $36.26 \pm 15.91$ & $0.819^{*}$ \\
$\begin{array}{l}\text { Clinical effect time of } \\
3^{\text {rd }} \text { maintenance }\end{array}$ & $38.4(24.5-67.0)$ & $39.9(23.7-48.0)$ & $0.897^{* *}$ \\
$\begin{array}{l}\text { Clinical effect time of } \\
4^{\text {th }} \text { maintenance }\end{array}$ & $29.0(18.0-40.0)$ & $39.4(36.2-44.3)$ & $0.355^{* *}$ \\
$\begin{array}{l}\text { Clinical effect time of } \\
5^{\text {th }} \text { maintenance }\end{array}$ & $36.25 \pm 12.23$ & $37.73 \pm 11.09$ & $0.732^{*}$ \\
\hline
\end{tabular}

*: independent samples t-test; **: Mann Whitney U test. 


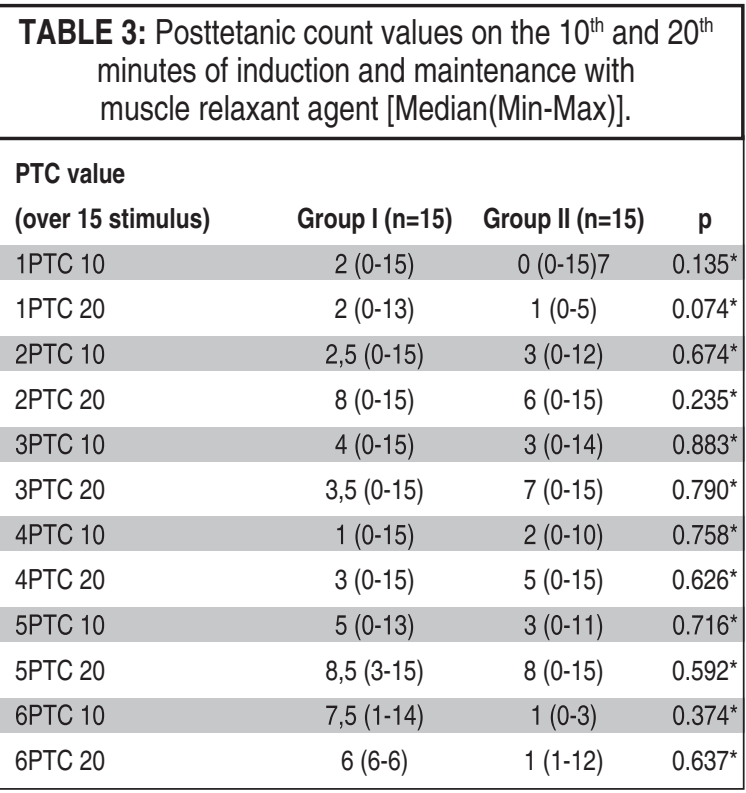

*: Mann Whitney U test.

PTC: Posttetanic Count; 1PTC10, 20: PTC values of $10^{\text {th }}$ and $20^{\text {th }}$ minutes after the induction, 2PTC10, 20: $10^{\text {th }}$ and $20^{\text {th }}$ minutes PTC values after $1^{\text {st }}$ maintenance muscle relaxant, $3 \mathrm{PTC} 10,20: 10^{\text {th }}$ and $20^{\text {th }}$ minutes PTC values after $2^{\text {nd }}$ maintenance muscle relaxant, 4PTC10, 20: $10^{\text {th }}$ and $20^{\text {th }}$ minutes $\mathrm{PTC}$ values after $3^{\text {rd }}$ maintenance muscle relaxant, 5PTC10, 20: $10^{\text {th }}$ and $20^{\text {th }}$ minutes PTC values after $4^{\text {th }}$ maintenance muscle relaxant, $6 \mathrm{PTC} 10,20: 10^{\text {th }}$ and $20^{\text {th }}$ minutes PTC values after $5^{\text {th }}$ maintenance muscle relaxant.

\begin{tabular}{|c|c|c|c|}
\hline \multicolumn{4}{|c|}{$\begin{array}{l}\text { TABLE 4: Time for the existence of TOF1 during } \\
\text { recovery after induction and maintenance with muscle } \\
\text { relaxant agent [Mean } \pm \text { SD or Median (Min-Max)]. }\end{array}$} \\
\hline \multicolumn{4}{|l|}{ Time for the existence of } \\
\hline TOF1 (min) & Group $1(n=15)$ & Group $2(n=15)$ & $p$ \\
\hline Induction TOF1 & $30.02 \pm 9.16$ & $31.83 \pm 8.88$ & $0.587^{*}$ \\
\hline $1^{\text {st }}$ maintenance TOF1 & $24.91 \pm 8.15$ & $24.39 \pm 8.15$ & $0.868^{*}$ \\
\hline $2^{\text {nd }}$ maintenance TOF1 & $27.72 \pm 10.69$ & $25.89 \pm 10.40$ & $0.663^{*}$ \\
\hline $3^{\text {rd }}$ maintenance TOF1 & $30.89 \pm 12.43$ & $26.95 \pm 7.07$ & $0.390^{*}$ \\
\hline \multirow[t]{2}{*}{$4^{\text {th }}$ maintenance TOF1 } & 23.18 & 26.00 & $0.431^{\star \star}$ \\
\hline & $(16.80-38.00)$ & $(20.00-40.50)$ & \\
\hline \multirow[t]{2}{*}{$5^{\text {th }}$ maintenance TOF1 } & 23.38 & 34.43 & $0.248^{* \star}$ \\
\hline & $(17.00-29.75)$ & $(22.50-38.07)$ & \\
\hline
\end{tabular}

*: independent samples t-test; **: Mann Whitney U test.

TOF1, during recovery, after induction and maintenance with muscle relaxant agent (Table 4$)(\mathrm{p}=$ $0.360)$.

There was no statistically significant difference between the groups in duration TOF 0.9, TOF 2580 time, reversal time, and TOFR values on the $10^{\text {th }}$, $20^{\text {th }}$ and $30^{\text {th }}$ minutes in SICU (Table 5) $(\mathrm{p}=0.714)$.
Residual block was found approximately in $30 \%$ of the patients according to TOFR in SICU. The residual block rate increased on $10^{\text {th }}$ minute, and then decreased gradually (Table 6). Additional neostigmine and atropin were administered to the patients with residual block. None of the patients developed postoperative complications related to residual block.

In our study, maintenance muscle relaxant was administered after TOF 2 response or diaphragm contraction. Before maintenance dose was administered, TOF 2 response was received alone in 71 of 96 measures (74\%) while in 25 measures (26\%), diaphragm contracted. TOF 2 response existed simultaneously with diaphragm contraction during 15 of 25 measures. TOF1 response was seen in 17 of 25 measures with diaphragm contraction whereas diaphragm contracted without TOF2 and TOF1 responses in 8 measures.

TABLE 5: Duration TOF 0.9, TOF 25-80 time, reversal time, and TOFR values [Median(Min-Max)].

\begin{tabular}{|lccc|}
\hline & Group 1 $(\mathrm{n}=15)$ & Group 2 $(\mathrm{n}=15)$ & $\mathbf{p}$ \\
Duration TOF 0.9 & 60.16 & 58.61 & $0.373^{*}$ \\
& $(27.50-96.00)$ & $(40.16-85.16)$ & \\
TOF 25-80 (min) & $5.98(2.0-15.0)$ & $5.30(3.0-20.0)$ & $0.934^{*}$ \\
Reversal time $(\mathrm{min})$ & 8.82 & 8.59 & $0.330^{*}$ \\
& $(2.17-25.00)$ & $(2.87-33.39)$ & \\
TOFR in SICU $\left(10^{\text {th }}\right.$ min) & $96(60-100)$ & $91(55-100)$ & $0.154^{*}$ \\
TOFR in SICU $\left(20^{\text {th }}\right.$ min $)$ & $96(70-100)$ & $94(75-100)$ & $0.582^{*}$ \\
TOFR in SICU $\left(30^{\text {th }}\right.$ min $)$ & $100(86-100)$ & $96(84-100)$ & $0.205^{*}$ \\
*: Mann Whitney U test. & & & \\
\hline
\end{tabular}

${ }^{*}:$ Mann Whitney $\mathrm{U}$ test.

TABLE 6: Ratio of the patients with TOFR below $90 \%$ to total number and the lowest TOFR values in SICU.

\begin{tabular}{|c|c|c|}
\hline $\begin{array}{l}\text { Ratio of the patients with } \\
\text { TOFR }<90 \% \text { to total number and } \\
\text { the lowest TOFR values }\end{array}$ & Group $1(n=15)$ & Group2 $(n=15)$ \\
\hline $\begin{array}{l}\text { Ratio of } 10^{\text {th }} \text { minute } \\
\text { (and the lowest TOFR values) }\end{array}$ & $\begin{array}{l}26 \% \\
(60 \%)\end{array}$ & $\begin{array}{l}40 \% \\
(50 \%)\end{array}$ \\
\hline $\begin{array}{l}\text { Ratio of } 20^{\text {th }} \text { minute } \\
\text { (and the lowest TOFR values) }\end{array}$ & $\begin{array}{l}13 \% \\
(70 \%)\end{array}$ & $\begin{array}{l}26 \% \\
(75 \%)\end{array}$ \\
\hline $\begin{array}{l}\text { Ratio of } 30^{\text {th }} \text { minute } \\
\text { (and the lowest TOFR values) }\end{array}$ & $\begin{array}{c}6 \% \\
(86 \%)\end{array}$ & $\begin{array}{l}13 \% \\
(84 \%)\end{array}$ \\
\hline
\end{tabular}


An average dose of $93.06 \mathrm{mg}$ epidural bupivacaine was used in Group 1. There was no statistically significant difference between the groups in the requirements of propofol and vecuronium ( $\mathrm{p}=0.138$ and $\mathrm{p}=0.722$, respectively). On the other hand, alfentanil usage was lower in Group 1 compared to Group 2 ( $\mathrm{p}=0.017$ ) (Table 7).

\section{DISCUSSION}

In the present study, we demonstrated that epidural bupivacaine reduced intraoperative alfentanil consumption, and had no significant effect on propofol and vecuronium requirements in TEA combined with TIVA during thoracic surgery. In addition, we showed that epidural bupivacaine in the present dose had no effect on the NMB features such as duration, intensity, reversal and the characteristics of residual block related to vecuronium.

The optimal anesthetic technique has not been described for pulmonary resections. General anesthesia combined with epidural anesthesia provides an excellent analgesia and muscle relaxation during surgeries related to thorax and abdomen. Epidural block reduces the need for general anesthetics during combined anesthesia. Providing a sufficient depth of anesthesia is essential for endotracheal tube toleration and ventilation. Therefore, it is important to determine the amount of epidural drugs to provide adequate anesthetic state. ${ }^{3-5}$

Administration of the local anesthetics with different routes has been showed to reduce the induction and maintenance doses of inhalation anesthetics and propofol. ${ }^{11-14}$

In a related article, Agarwal et al. put forward that propofol and vecuronium doses were significantly lower in epidural bupivacaine group com-

\begin{tabular}{|lccc|}
\hline \multicolumn{4}{|c|}{ TABLE 7: The requirements of intraoperative anesthetic } \\
agents (Mean \pm SD). \\
\hline The anesthetic agents & Group $1(\mathrm{n}=15)$ & Group $2(\mathrm{n}=15)$ & $\mathrm{p}$ \\
Propofol $(\mathrm{mg} / \mathrm{kg} / \mathrm{h})$ & $4.72 \pm 0.84$ & $5.14 \pm 0.62$ & 0.138 \\
Alfentanil $(\mathrm{mg} / \mathrm{kg} / \mathrm{h})$ & $0.041 \pm 0.01$ & $0.051 \pm 0.011$ & $0.017^{*}$ \\
Vecuronium $(\mathrm{mg} / \mathrm{kg} / \mathrm{h})$ & $0.04 \pm 0.02$ & $0.043 \pm 0.016$ & 0.722 \\
\hline
\end{tabular}

*p: Group 1 vs Group 2. pared to control group. ${ }^{2}$ The authors administered an average dose of $34 \mathrm{mg}$ epidural bupivacaine, whereas we used $93.06 \mathrm{mg}$. The higher dose of epidural bupivacaine was attributed to the use of bupivacaine both in bolus and infusion in our study. We found that TEA combined with TIVA reduced the dose of propofol and alfentanil, but only the difference in alfentanil dose was significant. The lower dose of alfentanil in Group 1 might be due to blockade of the noxious stimuli-induced reflex response by epidural bupivacaine. The results of previous articles concerning the effects of epidural local anesthetics on muscle relaxant agents have been incompatible. ${ }^{2,15-17}$ Donati and Fortier commented that the results of a high effect of epidural bupivacaine on vecuronium dose in Agarwal's study was not compatible with the previous studies. ${ }^{2,17}$ Therefore, the effects of epidurally given local anesthetics on NMB is a challenging issue that still needs to be studied. The differences of the results among similar studies might be caused by various anesthetic agents, doses, methods and types of the operations.

In the study by Li et al., epidural ropivacaine did not decrease the necessity for propofol significantly during combined anesthesia. ${ }^{15}$ One of the reasons for decreasing of propofol maintenance dose at Agarwal's study is that ephedrine used during the hypotension increased the BIS value, as Sinha and Unnikrishnan have interpreted. ${ }^{2,18}$ They have stated thus, propofol need may be changed. ${ }^{18}$ Even is not statistically significant, a little decrease is observed at the mean propofol values in our study.

Toft et al. found significant difference in PTC value on $10^{\text {th }}$ minute, and concluded that epidural bupivacaine increased the depth of NMB caused by atracurium. ${ }^{19}$ Bupivacaine lengthened the clinical effect time of induction dose, induction TOF 1 time, and reversal time of NMB in their trial. In our study, we found epidural bupivacaine did not affect $10^{\text {th }}, 20^{\text {th }}$ and $30^{\text {th }}$ minute values and NMB reversal time. Toft et al. also stated that onset time, clinical effect time of muscle relaxant in maintenance, and TOF 25-80 values were similar between the groups. ${ }^{19}$ These findings were in compliance 
with the results of our study. Toft et al. used more than 150 mg epidural bupivacaine in their study. ${ }^{19}$

Suzuki et al. observed that epidural mepivacaine extended the onset time and the reversal time of NMB-induced with vecuronium significantly. ${ }^{16}$ In a study conducted with children, it was found that vecuronium was slightly more potent in epidural bupivacaine group. However, the authors did not report any difference between the two groups in NMB reversal time. ${ }^{20}$ We considered that the present dose of epidural bupivacaine was not enough to potentiate NMB in our study.

The contraction of diaphragm without TOF2 or TOF1 responses in various measurements before the administration of muscle relaxant displays that TOF1 and TOF2 values may not be adequate indicators to maintain diaphragm relaxation during thoracic anesthesia. Probably, NMB may be adjusted to the PTC values reflecting deeper block levels.

Dhonneur et al. have proven that PTC values $\leq 5$ show deep NMB for diaphragm when measured from adductor pollicis muscle. ${ }^{21}$ The TOF values measured from corrugator supercillii muscle failed to reveal deep NMB of diaphragm. It has been shown that pharyngeal and upper esophageal sphincter function, thus a safe swallowing function, can be fulfilled only after TOFR values $>0.9 .{ }^{22}$ In other words, the risk of regurgitation and aspiration continues until TOFR $>0.9$. Therefore, we considered the TOFR below $90 \%$ as residual block in SICU. There was no significant difference between the groups in terms of residual block in this study. Additional neostigmine and atropine were administered uneventfully to 2 patients with the lowest TOFR of $50 \%$ and $60 \%$ from each group in SICU. Debaene et al. have pointed out that $45 \%$ of the patients experienced residual curarization in the recovery room. ${ }^{23}$ In previous researches, NMB recovery does not reach to the level of TOFR $\geq 0.8$ for a long time even after antagonization. The objective neuromuscular monitoring methods are recommended for safe recovery in routine clinical practice. ${ }^{24-27}$

\section{CONCLUSIONS}

In the present study, it was demonstrated that epidurally given bupivacaine decreased alfentanil consumption while it did not alter propofol or vecuronium requirement during TEA combined with TIVA in thoracic surgery. We also observed that epidural bupivacaine in the present dose had no effect on duration, intensity, reversal time or residual block characteristics of the NMB. This study indicates that block depth of TOF 1 and TOF 2 is insufficient to show paralysis of the diaphragm. The residual block of 26-40\% supports the necessity of neuromuscular monitoring and adequate antagonism in SICU. This study has shown that further studies should be performed to define the effect of an epidural local anesthetic on the issue of the NMB in clinical practice.

\section{Acknowledgement}

We appreciate the help of Mete Okan Cander for the English translation of this article.

\section{REFERENCES}

1. Iselin-Chaves IA, Flaishon R, Sebel PS, Howell S, Gan TJ, Sigl J, et al. The effect of the interaction of propofol and alfentanil on recall, loss of consciousness, and the Bispectral Index Anesth Analg 1998;87(4):949-55.

2. Agarwal A, Pandey R, Dhiraaj S, Singh PK, Raza M, Pandey CK, et al. The effect of epidural bupivacaine on induction and maintenance doses of propofol (evaluated by bispectral index) and maintenan- ce doses of fentanyl and vecuronium. Anesth Analg 2004;99(6):1684-8, table of contents.

3. Mangano DT. Perioperative cardiac morbidity. Anesthesiology 1990;72(1):153-84.

4. Garutti I, Quintana B, Olmedilla L, Cruz A, Barranco M, Garcia de Lucas E. Arterial oxygenation during one-lung ventilation: combined versus general anesthesia. Anesth Analg 1999;88(3):494-9.

5. Lo Gerfo P. Local/regional anesthesia for thy- roidectomy: evaluation as an outpatient procedure. Surgery 1998;124(6):975-8; discussion 978-9.

6. Hodgson PS, Liu SS, Gras TW. Does epidural anesthesia have general anesthetic effects? A prospective, randomized, double- blind, placebo-controlled trial. Anesthesiology 1999; 91(6):1687-92.

7. Nordmark J, Rydqvist B. Local anaesthetics potentiate $\mathrm{GABA}$-mediated $\mathrm{Cl}$ - currents by inhibiting GABA uptake. Neuroreport 1997;8(2):465-8. 
8. Viby-Mogensen J, Engbaek J, Eriksson LI, Gramstad L, Jensen E, Jensen FS, et al. Good clinical research practice (GCRP) in pharmacodynamic studies of neuromuscular blocking agents. Acta Anaesthesiol Scand 1996:40(1):59-74.

9. Fuchs-Buder T, Claudius C, Skovgaard LT, Eriksson LI, Mirakhur RK, Viby-Mogensen J; $8^{\text {th }}$ International Neuromuscular Meeting. Good clinical research practice in pharmacodynamic studies of neuromuscular blocking agents II: the Stockholm revision. Acta Anaesthesiol Scand 2007;51(7):789-808.

10. Stoelting RK, Dierdorf SF. Anesthesia and CoExisting Disease. 3rd ed. New York: ChurcillLivingstone; 1993. p.1-678.

11. Ben-Shlomo I, Tverskoy M, Fleyshman G, Cherniavsky G. Hypnotic effect of i.v. propofol is enhanced by i.m. administration of either lignocaine or bupivacaine. Br J Anaesth 1997; 78(4):375-7.

12. Senturk M, Pembeci K, Menda F, Ozkan T, Gucyetmez B, Tugrul M, et al. Effects of intramuscular administration of lidocaine or bupivacaine on induction and maintenance doses of propofol evaluated by bispectral index. $\mathrm{Br} \mathrm{J}$ Anaesth $2002 ; 89(6): 849-52$.

13. Tverskoy M, Fleyshman G, Bachrak L, Ben-Shlomo I. Effect of bupivacaine-induced spinal block on the hypnotic requirement of propofol. Anaesthesia 1996;51(7):652-3.
14. Eappen S, Kissin I. Effect of subarachnoid bupivacaine block on anesthetic requirements for thiopental in rats. Anesthesiology 1998;88(4): 1036-42.

15. Li Y, Zhu S, Yan M. Combined general/epidural anesthesia (ropivacaine $0.375 \%$ ) versus general anesthesia for upper abdominal surgery. Anesth Analg 2008;106(5):1562-5, table of contents

16. Suzuki T, Mizutani H, Ishikawa K, Miyake E, Saeki S, Ogawa S. Epidurally administered mepivacaine delays recovery of train-of-four ratio from vecuronium-induced neuromuscular block. Br J Anaesth 2007;99(5):721-5.

17. Donati F, Fortier LP. Plasma bupivacaine concentrations are too low to explain reduced vecuronium requirement with an epidural. Anesth Analg 2005;101(3):925; author reply 925-6.

18. Sinha PK, Unnikrishnan KP. Reduction in requirement of propofol during combined epidural (bupivacaine) and general anesthesia guided by bispectral index. Anesth Analg 2005;101(2):613; author reply 613-4.

19. Toft $P$, Kirkegaard Nielsen $H$, Severinsen I, Helbo-Hansen HS. Effect of epidurally administered bupivacaine on atracurium-induced neuromuscular blockade Acta Anaesthesiol Scand 1990;34(8):649-52.

20. Taivainen $\mathrm{T}$, Meretoja OA, Rosenberg PH. The effect of epidural bupivacaine on vecuronium-induced neuromuscular blockade in chil- dren. Acta Anaesthesiol Scand 1994;38(5): 453-6.

21. Dhonneur G, Kirov K, Motamed C, Amathieu R, Kamoun W, Slavov V, et al. Post-tetanic count at adductor pollicis is a better indicator of early diaphragmatic recovery than train-offour count at corrugator supercilii. $\mathrm{Br} J$ Anaesth 2007;99(3):376-9.

22. Eriksson LI. The effects of residual neuromuscular blockade and volatile anesthetics on the control of ventilation. Anesth Analg 1999;89(1):243-51.

23. Debaene B, Plaud B, Dilly MP, Donati F. Residual paralysis in the PACU after a single intubating dose of nondepolarizing muscle relaxant with an intermediate duration of action. Anesthesiology 2003;98(5):1042-8.

24. Murphy GS, Szokol JW, Marymont JH, Franklin M, Avram MJ, Vender JS. Residual paralysis at the time of tracheal extubation. Anesth Analg 2005;100(6):1840-5.

25. Kopman AF, Kopman DJ, Ng J, Zank LM. Antagonism of profound cisatracurium and rocuronium block: the role of objective assessment of neuromuscular function. J Clin Anesth 2005;17(1):30-5.

26. Kopman AF, Sinha N. Acceleromyography as a guide to anesthetic management: a case report. J Clin Anesth 2003;15(2):145-8.

27. Fuchs-Buder T. [Monitoring of residual neuromuscular block]. Anaesthesist 2000;49 (Suppl 1):S20-2. 